\title{
Determination of Groundwater System by Using Hydroisotope Method of Sei Bingei and Surrounding Areas, Langkat Regency, North Sumatra
}

\author{
Azmin Nuha ${ }^{1}$, Heru Hendrayana*1, Agus Budhie Wiyatna ${ }^{2}$, Doni Prakasa Eka Putra ${ }^{1}$, \\ and Azwar Satrya Muhammad ${ }^{3}$ \\ ${ }^{1}$ Department of Geological Engineering, Faculty of Engineering, Universitas Gadjah Mada, Yogyakarta, Indonesia \\ ${ }^{2}$ Department of Nuclear Engineering and Engineering Physics, Universitas Gadjah Mada, Indonesia \\ ${ }^{3}$ Water Resources and Process Department, Aqua Danone, Indonesia
}

\begin{abstract}
Groundwater plays an essential role in the supply of water for various purposes, so the use of groundwater must also pay attention to the balance and preservation of the resource itself. The formation of springs can be used as a reference to evaluate the quantity, quality, and continuity of the flow of water coming out of the spring. The shape and size of the spring recharge area are significant for determining the spring protection area, both in quantity and quality. Comprehensive research into the hydrogeological system is carried out through geological, hydrogeological, and hydroisotope studies. The purposes of this study are (1) to determine the LMWL (Local Meteoric Water Line) of the Sei Bingei Region, (2) to determine the recharge area for the Sei Bingei area and (3) to determine the genesis or origin of groundwater that appears in the Sei Bingei area. To answer the objectives, the campaign of water sampling of 23 groundwater and 15 rainwater samples were taken during different months and measure for the ${ }^{2} \mathrm{H} /{ }^{1} \mathrm{H}(\delta \mathrm{D})$ and ${ }^{18} \mathrm{O} /{ }^{16} \mathrm{O}$ $\left(\delta^{18} \mathrm{O}\right)$ isotope ratios. Isotopic ratios are used to assess the origin and recharge elevation of water. The results of the study are (1) the LMWL (Local Meteoric Water Line) equation in the Langkat area is $\delta \mathrm{D}=8.052 \times \delta^{18} \mathrm{O}+14.162$, (2) the main groundwater recharge area is located above 883 masl and (3) based on its isotopic ratios, groundwater in the study area can be differentiated into 3 genesis group: (a) Genesis-A Groundwater Group representing shallow-local groundwater system originated from local direct rainfall, $(b)$ Genesis-B Groundwater Group is the main deep groundwater system in the research with the lowest value of the isotopic ratio of $\delta^{18} \mathrm{O}$ and $\delta \mathrm{D}$, and (c) Genesis-C Groundwater Group is groundwater which it may come from the intermediate system between shallow and deeper groundwater system.
\end{abstract}

Keywords: Groundwater genesis · Hydroisotope · Groundwater recharge area.

\section{BACKGROUND}

Groundwater is a resource that has an essential role in providing water needs for various purposes, so the use of groundwater must pay attention to the balance and its preservation. Groundwater is one of the water resources that has now become a national problem, so it needs

\footnotetext{
${ }^{*}$ Corresponding author: H. HENDRAYANA, Department of Geological Engineering, Universitas Gadjah Mada. Jl. Grafika 2 Yogyakarta, Indonesia. E-mail: heruha@ugm.ac.id
}

concrete steps to minimize the negative impacts caused by groundwater exploitation activities. Research on springs is fundamental to explain the origin of groundwater formation in springs. The genesis of a spring can be used as a reference to evaluate the quantity, quality, and continuity of water flow at a spring. Besides, knowing the shape and extent of the recharge area of spring is essential to determine the conservation area for the spring.

The application of hydroisotope technology 
has been used to determine groundwater conservation areas with high accuracy for the benefit of environmental protection at the Wonosobo Region (Wijatna et al., 2017). Hendrayana et al. (2019) used a similar technique to determine the origin of groundwater in springs for spring protection at Mambal Region. The Sei Bingei area is a new area for the development of residential and industrial areas. The food and beverage industry is developing in this area, it is necessary to protect water resources to ensure the continuity of the industrial activities. Comprehensive research on the hydrogeological system of the Sei Bingei area through hydro-isotope studies is used to determine the recharge area for water sources, including the shape and extent accurately so that the water conservation program can be optimally achieved.

Based on the above facts, the purpose of this study is to determine the groundwater flow system and the origin of groundwater in the Sei Bingei and surrounding areas. The research objectives were (1) to determine the LMWL (Local Meteoric Water Line) of the Sei Bingei Region, (2) to determine the groundwater recharge area for the Sei Bingei Region and (3) to determine the genesis or origin of groundwater that appears in the Sei Bingei Region.

\section{LOCATION}

The research area was in the Sei Bingei area, Langkat Regency, North Sumatra Province (Figure 1). The delineation of sub-watersheds borders the study area by considering local geological conditions. The study area is volcanic hills with gentle slopes to steep slopes and in the form of gently sloping terrain and steep slopes in the south. Elevation between 25-2,200 masl. Geologically, the upstream area consists of massive volcanic rocks in the form of andesite and dacite intrusion which are covered by autoclastic breccia and lava flows, whereas in the downstream areas dominated by lahar deposits in the form of pebbly sand and pebbly clay.

\section{TheOreticAl Background}

According to the hydrological cycle, groundwater comes from the infiltration of rainwater towards the subsurface. The surface water is susceptible to be evaporation, which degree of evaporation will change the isotopic composi- tion of surface water. While the infiltrated water is shielded by the aquifer from evaporation, thus preserving the isotopic composition of the rainwater. The Groundwater flows in aquifers as shallow groundwater and deep groundwater. Shallow groundwater has the short circulating with a near exit through a locally-fed groundwater system.

Meanwhile, the deeply-circulating groundwater system has exit points in regionally-fed spring (Mazor, 2004). The isotopic composition of the deep groundwater type is typically calculated using the rainwater data. The derived isotopic values, in terms of Deuterium $\left({ }^{2} \mathrm{H}\right)$ and Oxygen-18 $\left({ }^{18} \mathrm{O}\right)$, are collectively called the Meteoric Water Index (MWI) (Salonga, 2015) or Meteoric Water Line (Crawford et al., 2014). IAEA (2014) defined that the Global Meteoric Water Line (GMWL) used to $\delta^{2} \mathrm{H}=8 \delta^{18} \mathrm{O}+$ 10. The primary source $\delta^{2} \mathrm{H}$ and $\delta^{18} \mathrm{O}$ data for GMWL is the Global Network of Isotope in Precipitation (GNIP) globally. The local precipitation data is called Local Meteoric Water Line (LMWL), (Clark and Fritz,1997).

Local Meteoric Water Line (LMWL) is a linear correlation of $\delta^{2} \mathrm{H}$ and $\delta^{18} \mathrm{O}$ contents observed in the specific area. LMWL is useful for the evaluation of the origin of waters. If the values of a pair of isotopes ratio determine from groundwater samples plot in the range of the Meteoric Water Line (MWL), it means that the groundwater was recharged by local precipitations and come from meteoric water. Local Meteoric Water Line (LMWL) is obtained from the analysis of monthly rainwater samples in a specific area. The LMWL is commonly used to determine the relationship of surface/groundwater to a potential precipitation source or to determine the degree of water evaporation enrichment (Crawford et al., 2014).

The determination of the groundwater recharge area is closely related to the calculation of LMWL because of LMWL as a basis for whether the water comes from rainwater/ surface water or groundwater. LMWL equation can be applied as a reference in natural isotope research to study groundwater dynamics in the hydrology cycle and to determine the groundwater recharge area (Mook and Rozanski, 2000).

To determine the effect of elevation and rain- 


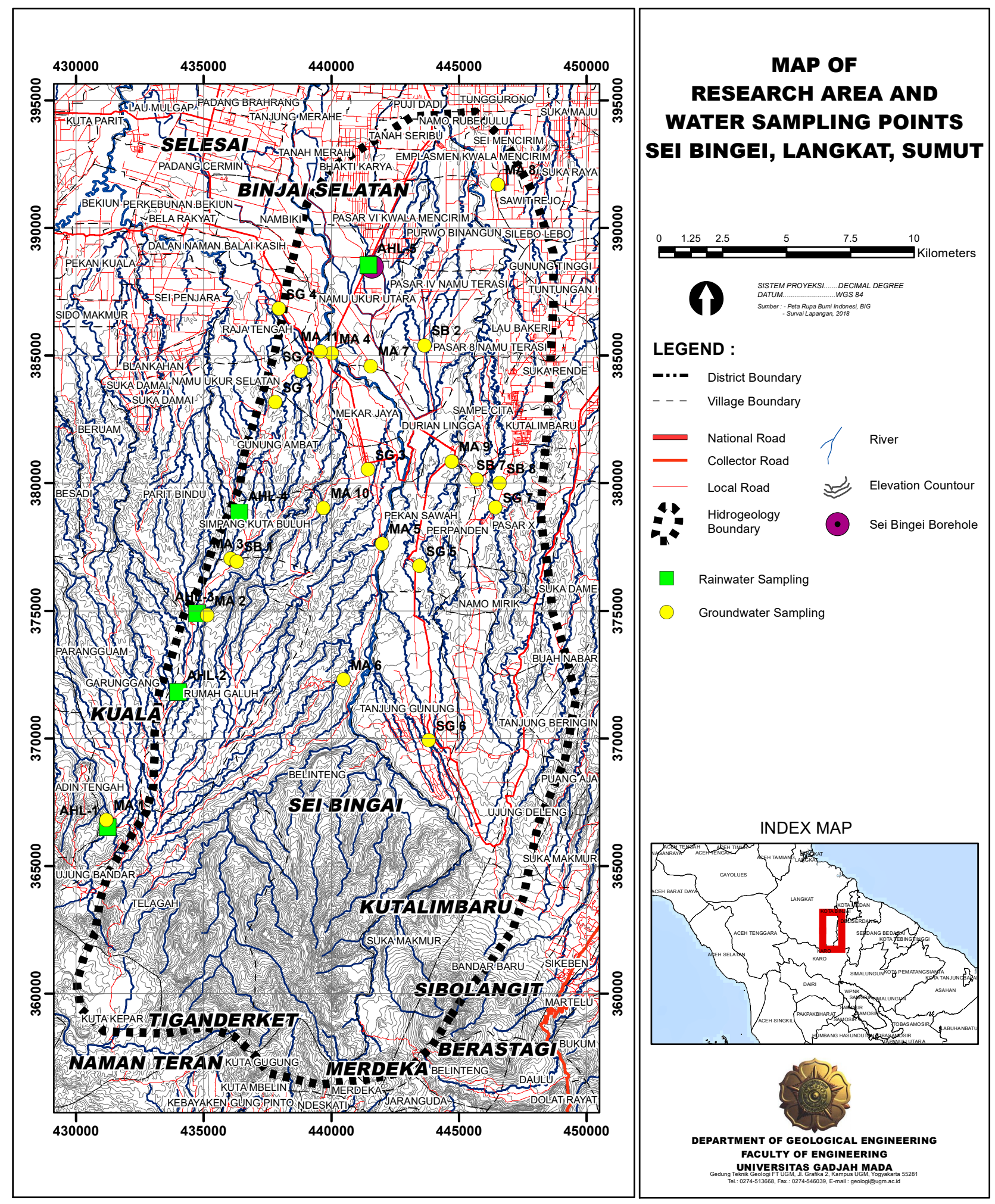

FIGURE 1. Map of the research area and water sampling points. 
fall on the rainwater isotopes composition, measurements, and analysis of ${ }^{2} \mathrm{H} /{ }^{1} \mathrm{H}$ and ${ }^{18} \mathrm{O} /{ }^{16} \mathrm{O}$ isotope ratios were performed. The equation resulting from the influence of elevation on the isotope composition $\left(\delta^{18} \mathrm{O}, \delta \mathrm{D}\right)$ of rainfall that falls in the Langkat region is called the Local Meteoric Water Line (LMWL)Langkat. The origin of groundwater can be predicted from the equation formed on the influence of elevation on the ${ }^{18} \mathrm{O}$ isotope ratio.

Standard mean ocean water (SMOW) is a standard for calibrating the composition of isotope ratio in the water sample. SMOW is from International Atomic Energy Agency (Mook and Rozanski, 2000). Based on the consideration that the largest evaporation process occurs in the ocean, so the seawater is used as a reference or SMOW. SMOW values according to international standards are presented in Table 1.

The value of $\mathrm{D} /{ }^{1} \mathrm{H}$ and ${ }^{18} \mathrm{O} /{ }^{16} \mathrm{O}$ isotope ratio from rainwater is expressed relative to SMOW and written with the notation $(\delta \mathrm{D} \%)$ and $\left(\delta^{18} \mathrm{O}\right.$ $\%$ ) using Equations [2,3].

$$
\begin{gathered}
\delta=\frac{R_{\text {smpl }}-R_{\text {std }}}{R_{\text {std }}} \times 1000 \\
\mathrm{D}=\frac{\left[\left(\frac{\mathrm{D}}{\mathrm{H}}\right)_{\mathrm{smpl}}-\left(\frac{\mathrm{D}}{\mathrm{H}}\right)_{\mathrm{SMOW}}\right]}{\left(\frac{\mathrm{D}}{\mathrm{H}}\right)_{\mathrm{SMOW}}} \times 1000 \\
{ }^{18} \mathrm{O}=\frac{\left[\left(\frac{{ }^{18} \mathrm{O}}{{ }^{16} \mathrm{O}}\right)_{\text {smpl }}-\left(\frac{18 \mathrm{O}}{{ }^{16} \mathrm{O}}\right)_{\mathrm{SMOW}}\right.}{\left(\frac{18 \mathrm{O}}{{ }^{16} \mathrm{O}}\right)_{\mathrm{SMOW}}} \times 1000
\end{gathered}
$$

with:

$R_{\text {smpl }}=$ isotope ratio $\left(\mathrm{D} /{ }^{1} \mathrm{H}\right.$ or $\left.{ }^{18} \mathrm{O} /{ }^{16} \mathrm{O}\right)$ water sample

$R_{\text {std }}=$ isotope ratio $\left(\mathrm{D} /{ }^{1} \mathrm{H}\right.$ or $\left.{ }^{18} \mathrm{O} /{ }^{16} \mathrm{O}\right)$ seawater

$\delta=$ isotope ratio $\left(\mathrm{D}\right.$ or $\left.{ }^{18} \mathrm{O}\right)$ water sample relative to the SMOW, \%o

$\delta \mathrm{D}=$ isotope ratio $\mathrm{D} /{ }^{1} \mathrm{H}$ water sample relative to SMOW, \%o

$\delta^{18} \mathrm{O}=$ isotope ratio ${ }^{18} \mathrm{O} /{ }^{16} \mathrm{O}$ water sample relative to SMOW, \%o
Most water (other than seawater) has an isotope ratio $\delta \mathrm{D}$ and $\delta^{18} \mathrm{O}<0 \%$ (negative value) or based on Equations 2 and 3 will apply (Craig, 1961): a) if $R_{\mathrm{smpl}}>R_{\mathrm{std}}$ then the value of $\delta_{\mathrm{smpl}}$ $>0$, means that the $\mathrm{D}$ or ${ }^{18} \mathrm{O}$ in the water sample is more productive (enriched) than SMOW; b) if $R_{\mathrm{smpl}}<R_{\mathrm{std}}$ then the value of $\delta_{\mathrm{smpl}}<0$, means that the $\mathrm{D}$ or ${ }^{18} \mathrm{O}$ level in the water sample is more reduced (depleted) than SMOW; c) if $R_{\mathrm{smpl}}=R_{\mathrm{std}}$, then $\delta_{\mathrm{smpl}}=0$, means that the $\mathrm{D}$ or ${ }^{18} \mathrm{O}$ in water $=\mathrm{SMOW}$ or also can be concluded that the water comes from seawater.

Rainwater sample has the ratio of $\delta \mathrm{D}$ and $\delta^{18} \mathrm{O}$ depleted than ratio $\delta \mathrm{D}$ and $\delta^{18} \mathrm{O}$ of seawater due to the higher of elevation, the lower of temperature, vapor will be condensed again. Rainwater that falls on the higher elevation has a lower $\delta \mathrm{D}$ and $\delta^{18} \mathrm{O}$ isotope ratio. This phenomenon cause's groundwater from higher elevation has $\delta \mathrm{D}$ and $\delta^{18} \mathrm{O}$ smaller than groundwater from the lower elevation (Craig, 1961).

Besides the elevation influence, $\delta \mathrm{D}$ and $\delta^{18} \mathrm{O}$ value also depend on rainfall intensity. The higher rainfall, $\delta \mathrm{D}$ and $\delta^{18} \mathrm{O}$ ratio of rainwater are getting depleted and the lower rainfall intensity will be more enriched. Due to the rainfall, pressure, and air temperature, and air humidity always fluctuated, so the value of $\delta \mathrm{D}$ and $\delta^{18} \mathrm{O}$ in every sample location should be calculated with this Equations [4,5].

$$
\begin{aligned}
\delta^{18} \mathrm{O} & =\frac{\sum_{i=1}^{n} P_{i} \delta_{i}^{18} \mathrm{O}}{\sum_{i=1}^{n} P_{i}} \\
\delta \mathrm{D} & =\frac{\sum_{i=1}^{n} P_{i} \delta_{i} \mathrm{D}}{\sum_{i=1}^{n} P_{i}}
\end{aligned}
$$

with:

$\delta^{18} \mathrm{O}=$ average isotope ratio ${ }^{18} \mathrm{O} /{ }^{16} \mathrm{O}$ relative to SMOW in rainwater, \%o

$\delta \mathrm{D}=$ average isotope ratio $\mathrm{D} /{ }^{1} \mathrm{H}$ relative to SMOW in rainwater, $\%$

$\delta_{i}^{18} \mathrm{O}=$ isotope ration ${ }^{18} \mathrm{O} /{ }^{16} \mathrm{O}$ relative to SMOW in rainfall to $(i), \%$

$\delta_{i} \mathrm{D}=$ isotope ration $\mathrm{D} /{ }^{1} \mathrm{H}$ relative to SMOW in rainfall to $(i), \%$ 
TABLE 1. Isotope ratio of SMOW (Craig, 1961).

\begin{tabular}{lllll}
\hline & Ratio, $\mathrm{H} / \mathrm{L}\left(=R_{\text {std }}\right)$ & Value, $\mathrm{H} / \mathrm{L}$ & \multicolumn{1}{c}{$\% \mathrm{H}$} & \multicolumn{1}{c}{$\% \mathrm{~L}$} \\
\hline \multirow{2}{*}{ Standard Mean Ocean } & $\mathrm{D} /{ }^{1} \mathrm{H}$ & 0.00015576 & 0.015574 & 99.984426 \\
Water (SMOW) & ${ }^{17} \mathrm{O} /{ }^{16} \mathrm{O}$ & 0.0003799 & 0.0379 & 99.76206 \\
& ${ }^{18} \mathrm{O} /{ }^{16} \mathrm{O}$ & 0.0020052 & 0.0020052 & 99.76206 \\
\hline
\end{tabular}

Note: $\mathrm{H}=$ Heavy isotopes and $\mathrm{L}=$ Light isotopes

$P_{i}=$ amount of rainfall between the sample $(i-1)$ to $(i)$, mm per month.

The value of $\delta \mathrm{D}$ and $\delta^{18} \mathrm{O}$ in some rainwater samples is linear and follow the Equation 6. Equation 6 depends on geographical factors, particularly concerning temperature, humidity, thickness, and precipitation. From rainwater samples taken globally through 91 rainfed stations worldwide, $d=10$, so it can be written as the Global Meteoric Water Line (GMWL) in the following formulas (Kresic and Stevanovic, 2010; Clark and Fritz, 1997; Craig, 1961).

$$
\delta \mathrm{D}=a \times \delta^{18} \mathrm{O}+d
$$

And for analysis of elevation influence to $\delta^{18} \mathrm{O}$ can be obtained from plotting graph of $\delta^{18} \mathrm{O}$ ratio vs. elevation, that will allow this linear Equation 7;

$$
\begin{gathered}
\delta^{18} \mathrm{O}=\alpha \times \text { elevation }-\beta \\
E=c \times \delta^{18} \mathrm{O}+d
\end{gathered}
$$

Based on Equation 7, if the data show the ratio of $\delta^{18} \mathrm{O}$ groundwater, then the elevation of the origin or groundwater recharge area can be estimated.

\section{Research Method}

The method to carry out this research is by conducting a campaign of water sampling of groundwater and rainwater samples also measure the ${ }^{2} \mathrm{H} /{ }^{1} \mathrm{H}$ and ${ }^{18} \mathrm{O} /{ }^{16} \mathrm{O}$ isotope ratios on the water samples. Isotopic ratios are used to assess the origin and recharge elevation of water. The groundwater sampling locations were carried out in existing springs and wells in the research area. Twenty-three groundwater samples from dug wells (SG), deep well/borehole (SB), and springs (MA) were sampled in September 2019 during the dry season. In the beginning, it was planned to take also rainwater sample but due to the long dry season, rainwater sampling can only be done starting at the beginning of the rainy season. Rainwater sampling (AHL) was carried out at 5 locations, representing upstream and downstream areas (high altitude to low altitude). Each location was taken three times in December 2018, January and February 2019 which have also different intensities of rainfall. The coordinates and elevation of rainwater sampling locations are presented in Table 2. The number of rainwater samples was 15 in total. To use rainfall data from Meteorology, Climatology, and Geophysics Agency (BMKG), the location of rainwater sampling is strive to be within the coverage radius of BMKG nearest rainfall monitoring station. Laboratory analysis of hydroisotope content was carried out at the Earth and Environmental Laboratory, PATIR-BATAN Jakarta. All groundwater and rainwater samples were analyzed to determine the isotope ratios $\delta \mathrm{D}$ and $\delta^{18} \mathrm{O}$ using the Liquid tool-Water Stable Isotope Analyzer (LWSIA)LGR DLT-100.

\section{Results AND DisCussion}

\subsection{Local Meteoric Water Line}

Determination of Local Meteoric Water Line (LMWL) is done by analyzing rainwater samples in 5 locations having different elevations. Following international conventions, the average mean ratio and the actual ratio of isotope $\mathrm{D} /{ }^{1} \mathrm{H}$ and ${ }^{18} \mathrm{O} /{ }^{16} \mathrm{O}$ of rainwater samples in December 2018, January and February 2019 must be stated relative to the Standard Mean Ocean Water (SMOW), which can be seen in Table 3. Every month rainfall is fluctuating and this phenomenon affects the isotope ratios $\delta \mathrm{D}$ and $\delta^{18} \mathrm{O}$. These results can be seen in the results of rainwater isotope ratio measurements at the same elevation and taken different months or different rainfall intensities, showing different values. Theoretically, the higher the rainfall, the smaller the isotope ratios $\delta \mathrm{D}$ and $\delta^{18} \mathrm{O}$. Con- 
TABLE 2. The coordinates and elevation of rainwater sampling locations in Langkat Regency, North Sumatra.

\begin{tabular}{|c|c|c|c|c|c|}
\hline \multirow{2}{*}{ No } & \multirow{2}{*}{ Code } & \multirow{2}{*}{ Location } & \multicolumn{2}{|c|}{ Coordinate (UTM) } & \multirow{2}{*}{$\begin{array}{l}\text { Elevation } \\
\text { (masl) }\end{array}$} \\
\hline & & & $\mathrm{X}$ & $\mathrm{Y}$ & \\
\hline 1 & AHL-1 & $\begin{array}{l}\text { Air Babarsari Pool Lau Kulap, Garunggang Village, } \\
\text { Kuala Sub District, Langkat Regency }\end{array}$ & 431232 & 366528 & 712 \\
\hline 2 & AHL-2 & $\begin{array}{l}\text { (Open Field) Rumah Galuh Village, Sei Bingei } \\
\text { Sub-District, Langkat Regency }\end{array}$ & 433987 & 371819 & 550 \\
\hline 3 & AHL-3 & $\begin{array}{l}\text { Tugu Juang } 45 \text { Rumah Galuh Village, Sei Bingei } \\
\text { Sub-District, Langkat Regency }\end{array}$ & 434733 & 374890 & 425 \\
\hline 4 & AHL-4 & $\begin{array}{l}\text { Telagah Str, Simpang Kuta buluh Village, Sei Bingei } \\
\text { Sub-District, Langkat Regency }\end{array}$ & 436388 & 378851 & 260 \\
\hline 5 & AHL-5 & $\begin{array}{l}\text { Namu Ukur Str, North Ukur Village, Sei Bingei } \\
\text { Sub-District, Langkat Regency }\end{array}$ & 441444 & 388563 & 85 \\
\hline
\end{tabular}

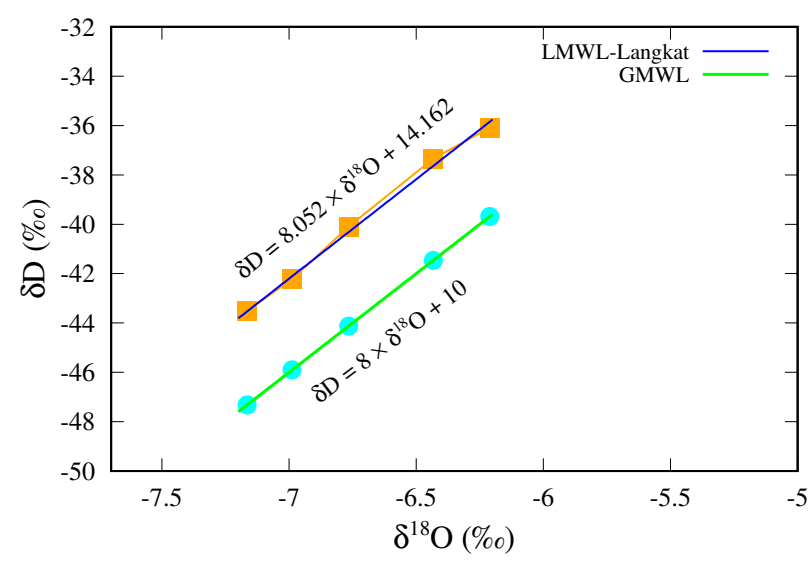

FIGURE 2. Langkat local meteoric water line (LMWL) compare to global meteoric water line (GMWL).

versely, the lower the rainfall, the value of the isotope ratios $\delta \mathrm{D}$ and $\delta^{18} \mathrm{O}$ will be even higher. Therefore the isotope ratios $\delta \mathrm{D}$ and $\delta^{18} \mathrm{O}$ for rainwater samples are averaged by taking into account the influence of monthly average rainfall values at each elevation. The results of the calculation of the isotope ratios $\delta \mathrm{D}$ and $\delta^{18} \mathrm{O}$ in rainwater by taking into account the variation in rainfall are presented in Table 4.

Based on rainwater isotope data of AHL-1, AHL-2, AHL-3, AHL-4, and AHL-5 as seen in Table 4 , the graph $\delta^{18} \mathrm{O}$ versus $\delta \mathrm{D}$ is made to obtain the LMWL curve in the Langkat region. Figure Figure 2 displays the LMWL curve relative to the Global Meteoric Water Line (GMWL) as a comparison. From Figure Figure 3 it is found that the LMWL-Langkat equation is $\delta \mathrm{D}$ $=8.052 \times \delta^{18} \mathrm{O}+14.162$, with the coefficient of determination $\left(R^{2}\right) 0.9949$ of the linear correlation.

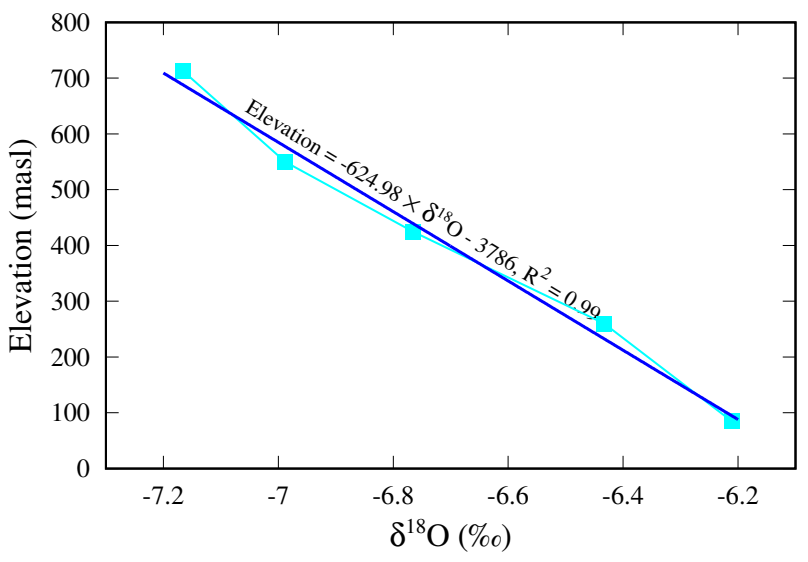

FIGURE 3. Elevation versus isotope ratio $\delta^{18} \mathrm{O}$ of rainwater.

Rainwater on of AHL-5 (85 masl) has a more enriched isotope ratio, $\delta \mathrm{D}=-36.093 \%$ and $\delta^{18} \mathrm{O}$ $=-6.211 \%$; and vice versa rainwater at high elevation sites, AHL-1 (712 masl) has more depleted isotope ratios, $\delta \mathrm{D}=-43.510 \%$ and $\delta^{18} \mathrm{O}$ $=-7.165 \%$ (Table 4 ). The results of this measurement are following the theory which states that the higher the elevation, the isotope ratios $\delta \mathrm{D}$ and $\delta^{18} \mathrm{O}$ in rainwater are depleted and vice versa.

\section{$5.2 \delta^{18} \mathrm{O}$ vs Recharge Elevation}

If the data in Table 4 draw to a graph representing the isotope ratio $\delta^{18} \mathrm{O}$ vs elevation $(E)$, the graph shows a linear relationship between both parameters and it is clearly shown that on the higher elevation, the isotope ratio $\delta^{18} \mathrm{O}$ rainwater is depleted (Figure 3), which can be calculated by the equation: Elevation $=-624.98 \times$ $\delta^{18} \mathrm{O}-3786$, with the coefficient of determination, $R^{2}=0.99905$. 
TABLE 3. The isotope ratio value of $\delta \mathrm{D}$ and $\delta^{18} \mathrm{O}$ of Langkat rainwater relative to SMOW.

\begin{tabular}{cccccccccc}
\hline \multirow{2}{*}{ No } & \multirow{2}{*}{ Code } & \multirow{2}{*}{ Elevation (masl) } & \multicolumn{3}{c}{$\delta \mathrm{D}, \% 0$} & & \multicolumn{3}{c}{$\delta^{18} \mathrm{O}, \% 0$} \\
\cline { 8 - 10 } & & & Dec-18 & Jan-19 & Feb-19 & & Dec-18 & Jan-19 & Feb-19 \\
\hline 1 & AHL-1 & 712 & -45.59 & -43.16 & -41.22 & & -7.32 & -7.15 & -6.98 \\
2 & AHL-2 & 550 & -43.11 & -42.37 & -40.88 & & -7.82 & -6.89 & -6.02 \\
3 & AHL-3 & 425 & -41.94 & -39.54 & -38.37 & & -7.49 & -6.69 & -5.91 \\
4 & AHL-4 & 260 & -38.94 & -36.89 & -35.82 & & -6.99 & -6.49 & -5.63 \\
5 & AHL-5 & 85 & -37.49 & -35.99 & -34.39 & & -6.76 & -6.29 & -5.39 \\
\hline
\end{tabular}

TABLE 4. Langkat rainwater isotope ratio as a function of elevation.

\begin{tabular}{|c|c|c|c|c|c|}
\hline \multirow{2}{*}{ No. } & \multirow{2}{*}{ Location } & \multirow{2}{*}{ Code } & \multirow{2}{*}{$\begin{array}{l}\text { Elevation } \\
\text { (masl) }\end{array}$} & \multicolumn{2}{|c|}{ Average isotope } \\
\hline & & & & $\delta \mathrm{D}, \% 0$ & $\delta^{18} \mathrm{O}, \%$ \\
\hline 1 & $\begin{array}{l}\text { Air Babarsari Pool Lau Kulap, Garunggang Village, } \\
\text { Kuala Sub-District, Langkat Regency }\end{array}$ & AHL-1 & 712 & -43.510 & -7.165 \\
\hline 2 & $\begin{array}{l}\text { (Open Field) Rumah Galuh Village, Sei Bingei } \\
\text { Sub-District, Langkat Regency }\end{array}$ & AHL-2 & 550 & -42.225 & -6.988 \\
\hline 3 & $\begin{array}{l}\text { Tugu Juang } 45 \text { Rumah Galuh Village, Sei Bingei } \\
\text { Sub-District, Langkat Regency }\end{array}$ & AHL-3 & 425 & -40.095 & -6.766 \\
\hline 4 & $\begin{array}{l}\text { Jalan Telagah, Simpang Kuta Buluh Village, Sei } \\
\text { Bingei Sub-District, Langkat Regency }\end{array}$ & AHL-4 & 260 & -37.344 & -6.433 \\
\hline 5 & $\begin{array}{l}\text { Namu Ukur Str, North Namu Ukur Village, Sei } \\
\text { Bingei Sub-District, Langkat Regency }\end{array}$ & AHL-5 & 85 & -36.093 & -6.211 \\
\hline
\end{tabular}

The above equation can be used to determine the recharge elevation of groundwater. As the isotopic ratio of $\delta^{18} \mathrm{O}$ assume to be similar after the water enters the groundwater system. Based on the above equation and the value $\delta^{18} \mathrm{O}$ on the groundwater samples listed in Table 5, it is concluded that on the case of springs and deep well in the research area, the recharge elevation comes mainly from an altitude above 883 masl (Figure 4).

There are two considerations regarding the result of the main recharge area. First, due to no rainwater sample coming from or near the top of the mountain (higher than 900 masl), the relationship between isotopic ratio $\delta^{18} \mathrm{O}$ with elevation may be used with concern. Two, the difference of sampling time and season between groundwater and rainwater sample may affect the result of the analysis. According to Clark (2015), there is an isotopic ratio sensitivity of the groundwater system to recharge frequency and drought. Groundwater near the water table may still fluctuate within 1 to 2 per mil for $\delta^{18} \mathrm{O}$ during the rainy and dry season.

\subsection{Groundwater Genesis and Groups}

Despite the above consideration, the isotope ratio data $\delta \mathrm{D}$ and $\delta^{18} \mathrm{O}$ of groundwater samples at least can be used to determine the genesis group of each groundwater sample relative to LMWL-Langkat (see Figure 5 and Figure 6). Based on Figure 5, the groundwater in the study area can be differentiated into 3 groundwater genesis, namely:

a. Genesis-A group is a groundwater source with isotope ratios similar to the ratio of rainwater isotopes that fall at the same elevation. Members of this group are MA-1 and SB-2. The groundwater of MA-1 and SB-2 does not come from the most recharge area elevation but comes directly from local rainwater.

b. Genesis-B group is a groundwater source with the commonly lowest value of isotopic ratios. There are 17 groundwater sources including SB Sei Bingei; and other sources, such as MA-2, MA-3, MA-4, MA5, MA-6, MA-7, MA-8, MA-10, MA-11, SB1, SG- 1, SG-2, SG-3, SG-4, SG-5, and SG-6. Most of this groundwater originated from an elevation above 883 masl. 


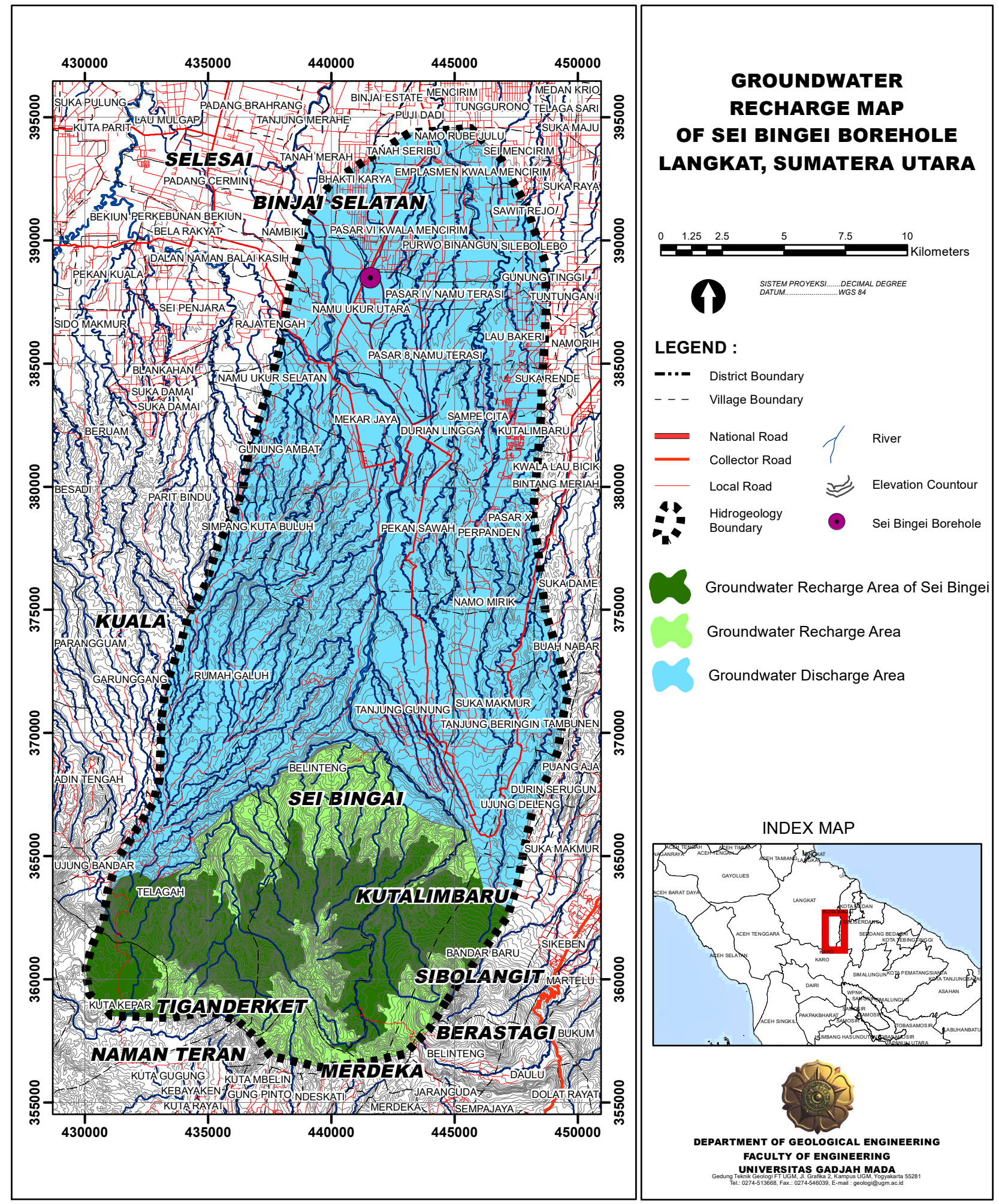

FIGURE 4 . The main groundwater recharge area according to isotope ratio $\delta^{18} \mathrm{O}$ of rainwater. 
TABLE 5. Isotope ratio $\delta \mathrm{D}$ and $\delta^{18} \mathrm{O}$ Langkat groundwater samples.

\begin{tabular}{|c|c|c|c|c|c|}
\hline No. & Location & Code & $\begin{array}{l}\text { Elevation } \\
\text { (masl) }\end{array}$ & $\delta^{18} \mathrm{O}(\%)$ & $\delta \mathrm{D}(\%)$ \\
\hline 1 & $\begin{array}{l}\text { Garunggang Village, Kuala } \\
\text { Sub-District }\end{array}$ & MA-1 & 705 & $-7.31 \pm 0.21$ & $-44.73 \pm 1.91$ \\
\hline 2 & $\begin{array}{l}\text { Tanjung Gunung Village, Sei Bingei } \\
\text { Sub-District }\end{array}$ & SG-6 & 445 & $-8.17 \pm 0.22$ & $-50.99 \pm 1.32$ \\
\hline 3 & $\begin{array}{l}\text { Rumah Galuh Village, Sei Bingei } \\
\text { Sub-District }\end{array}$ & MA-2 & 365 & $-8.13 \pm 0.02$ & $-50.99 \pm 0.92$ \\
\hline 4 & $\begin{array}{l}\text { Rumah Galuh Village, Sei Bingei } \\
\text { Sub-District }\end{array}$ & MA-3 & 339 & $-7.99 \pm 0.12$ & $-49.56 \pm 1.22$ \\
\hline 5 & $\begin{array}{l}\text { Rumah Galuh Village, Sei Bingei } \\
\text { Sub-District }\end{array}$ & SB-1 & 327 & $-8.18 \pm 0.52$ & $-50.62 \pm 1.23$ \\
\hline 6 & $\begin{array}{l}\text { Belinteng Village, Sei Bingei } \\
\text { Sub-District }\end{array}$ & MA-6 & 318 & $-8.08 \pm 0.09$ & $-48.78 \pm 1.41$ \\
\hline 7 & $\begin{array}{l}\text { Pekan Sawah Village, Sei Bingei } \\
\text { Sub-District }\end{array}$ & SG-5 & 282 & $-8.22 \pm 0.32$ & $-49.12 \pm 1.24$ \\
\hline 8 & $\begin{array}{l}\text { Belinteng Village, Sei Bingei } \\
\text { Sub-District }\end{array}$ & MA-10 & 220 & $-8.11 \pm 0.31$ & $-50.41 \pm 1.43$ \\
\hline 9 & $\begin{array}{l}\text { Pasar X Village, Kutalimbaru } \\
\text { Sub-District }\end{array}$ & SG-7 & 211 & $-7.64 \pm 0.84$ & $-45.61 \pm 1.28$ \\
\hline 10 & $\begin{array}{l}\text { Pekan Sawah Village, Sei Bingei } \\
\text { Sub-District }\end{array}$ & MA-9 & 189 & $-7.67 \pm 0.62$ & $-45.21 \pm 1.38$ \\
\hline 11 & $\begin{array}{l}\text { Pasar X Village, Kutalimbaru } \\
\text { Sub-District }\end{array}$ & SB-7 & 187 & $-7.64 \pm 0.98$ & $-45.95 \pm 1.72$ \\
\hline 12 & $\begin{array}{l}\text { Gergit, Gunung Ambat Village, Sei } \\
\text { Bingei Sub-District }\end{array}$ & SG-1 & 183 & $-7.95 \pm 0.41$ & $-48.55 \pm 2.41$ \\
\hline 13 & $\begin{array}{l}\text { Simpang Buruh, Belinteng, Sei Bingei } \\
\text { Sub-District }\end{array}$ & SG-3 & 180 & $-8.02 \pm 0.07$ & $-48.67 \pm 1.51$ \\
\hline 14 & $\begin{array}{l}\text { Belinteng Village, Sei Bingei } \\
\text { Sub-District }\end{array}$ & MA-5 & 179 & $-7.92 \pm 0.51$ & $-48.87 \pm 1.24$ \\
\hline 15 & $\begin{array}{l}\text { South Namu Ukur Village, Sei Bingei } \\
\text { Sub-District }\end{array}$ & SG-2 & 170 & $-8.21 \pm 0.08$ & $-50.98 \pm 1.31$ \\
\hline 16 & $\begin{array}{l}\text { Pasar X Village, Kutalimbaru } \\
\text { Sub-District }\end{array}$ & SB-8 & 168 & $-7.71 \pm 0.87$ & $-45.72 \pm 1.09$ \\
\hline 17 & $\begin{array}{l}\text { North Namu Ukur Village, Sei Bingei } \\
\text { Sub-District }\end{array}$ & MA-7 & 119 & $-8.17 \pm 0.61$ & $-50.24 \pm 1.12$ \\
\hline 18 & $\begin{array}{l}\text { Namu Terasi Village, Sei Bingei } \\
\text { Sub-District }\end{array}$ & SB-2 & 118 & $-6.21 \pm 0.43$ & $-36.18 \pm 1.31$ \\
\hline 19 & $\begin{array}{l}\text { South Namu Ukur Village, Sei Bingei } \\
\text { Sub-District }\end{array}$ & MA-11 & 107 & $-8.25 \pm 1.01$ & $-49.85 \pm 1.71$ \\
\hline 20 & $\begin{array}{l}\text { Sawit Rejo Village, Kutalimbaru } \\
\text { Sub-District }\end{array}$ & MA-8 & 105 & $-8.02 \pm 0.16$ & $-50.01 \pm 1.93$ \\
\hline 21 & $\begin{array}{l}\text { Raja Tengah Village, Kuala } \\
\text { Sub-District }\end{array}$ & SG-4 & 95 & $-8.23 \pm 0.32$ & $-50.23 \pm 0.86$ \\
\hline 22 & $\begin{array}{l}\text { North Namu Ukur Village, Sei Bingei } \\
\text { Sub-District }\end{array}$ & $\begin{array}{l}\text { SB Sei } \\
\text { Bingei }\end{array}$ & 94 & $-8.16 \pm 0.21$ & $-49.01 \pm 1.48$ \\
\hline 23 & $\begin{array}{l}\text { North Namu Ukur Village, Sei Bingei } \\
\text { Sub-District }\end{array}$ & MA-4 & 85 & $-8.01 \pm 0.08$ & $-50.15 \pm 1.22$ \\
\hline
\end{tabular}

Explanation: $\square=$ Group A-; $\square=$ Group B-; $\quad=$ Group C - 


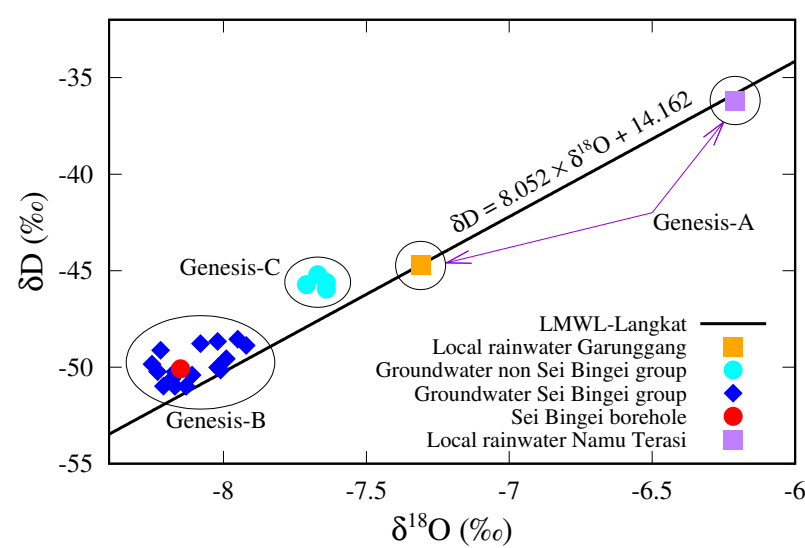

FIGURE 5. Isotope data of groundwater samples relative to LMWL-Langkat.

c. Genesis- $C$ group is groundwater source with isotope ratios of $\delta^{18} \mathrm{O}$ and $\delta \mathrm{D}$ are in between the Genesis-A and Genesis-B groundwater isotopes, so it can be interpreted that this may come from lower recharge area of 883 masl nor these groundwater source has no hydraulic interconnection with Genesis-A and Genesis-B groundwater. Members of this group are SG-7, SB-7, SB-8, and MA-9.

\section{CONCLUSION}

According to the result and discussion, there are several conclusion which can be drawn related to the objectives of the research as written below:

a. The Local Meteoric Water Line of Langkat area follows the equation; $\delta \mathrm{D}=8.052 \times$ $\delta^{18} \mathrm{O}+14.162$, this equation is based on the average data of rainwater taken between December 2018 to February 2019.

b. The main groundwater recharge in the research area is located above 883 masl, however, the value must be carefully used as there is a lack of rainwater sample coming from the top elevation of the near mountain and the different times of sampling between groundwater and rainwater samples.

c. Groundwater in the study area can be differentiated into 3 genesis group: (a) Genesis-A Groundwater Group representing shallow-local groundwater system originated from local direct rainfall, (b)
Genesis-B Groundwater Group is the main deep groundwater system in the research with the lowest value of the isotopic ratio of $\delta^{18} \mathrm{O}$ and $\delta \mathrm{D}$, and (c) Genesis-C Groundwater Group is groundwater which it may come from the intermediate system between shallow and deeper groundwater system.

\section{ACKNOWLEDGEMENTS}

The authors would like to thank all the parties that support the research project and the preparation of this article, especially for the AquaDanone-Indonesia (PT. Tirta Investama) and Department of Geological Engineering, Faculty of Engineering, University of Gadjah Mada. Any opinions, findings, conclusions expressed in this paper are those of authors and do not necessarily reflect the views of the employers or granting organizations.

\section{REFERENCES}

Clark, I.D. and Fritz, P. (1997) Environmental Isotopes in Hydrology. Lewis Publishers. Boca Raton, New York.

Clark, I. (2015) Groundwater Geochemistry and Isotopes, Taylor \& Francis Group, CRC Press, 421p.

Craig, H. (1961) Standard for reporting concentrations of deuterium and oxygen-18 in natural waters. Science, 133(3467), pp.1833-1834.

Crawford, J., Hughes, C.E., and Lykoudis, S. (2014) Alternative least squares methods for determining the meteoric water line, demonstrated using GNIP data. Journal of Hydrology, 519, pp. 23312340.

Hendrayana, H., Nuha, A., Wijatna, A.B., Muhammad, A.S. (2019) Hydrogen Isotope Study to Determine Groundwater Genesis in Mambal Spring, Bali, Indonesia, Proceeding of 11th Regional Conference on Geological and Geo-Resources Engineering-Innovations and Emerging Technologies for Responsible Mineral Resource Development, Eastwood Richmonde Hotel, Quezon City, Philippines.

IAEA, W. (2014) Global network of isotopes in precipitation. GNIP database.

Kresic, N. and Stevanovic, Z. (eds) 2010. Groundwater Hydrology of Springs: Engineering, Theory, Management, and Sustainability. Amsterdam, Butterworth-Heinemann (Elsevier); 573 pages.

Mazor, E. (2004) Chemical and isotopic groundwater hydrology (p. 453). New York: Marcel Dekker. Mook, W. and Rozanski, K. (2000) Environmental 


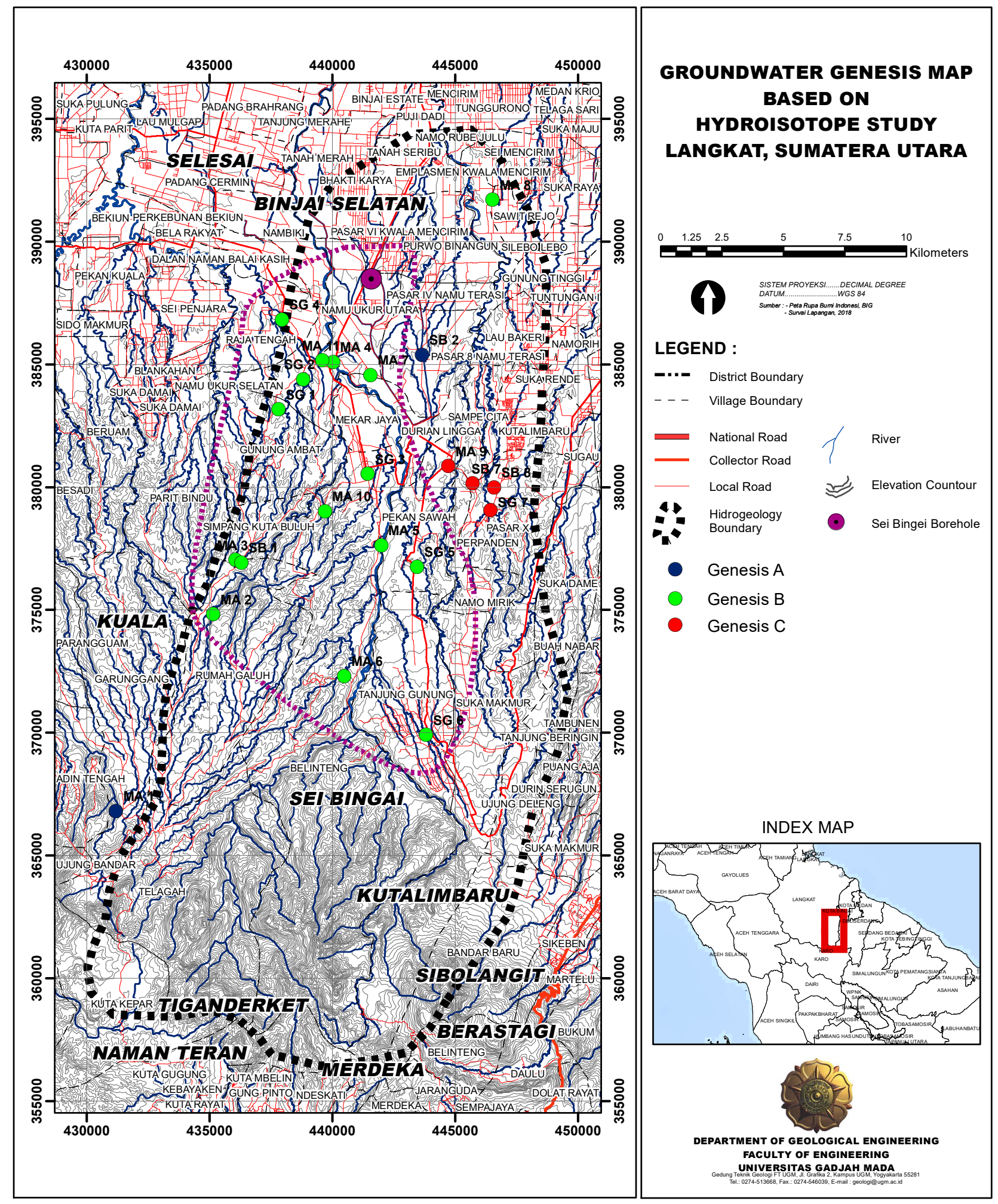

FIGURE 6. Group of groundwater genesis in the research area. 
isotopes in the hydrological cycle. IAEA Publish, $39 \mathrm{p}$.

Salonga, N.D. (2015) Estimating the isotopic composition of meteoric Water index in geothermal fields in the Philippines. In Proceedings of the World Geothermal Congress (p. 7).
Wijatna, A.B., Hendrayana, H., Aliyah, F., Muhammad, A.S. and Pratikno, B. (2018) Determination LMWL Wonosobo Area by Using Nuclear Technology, Case Study: Hydrogeology Study for Aqua Danone CSR Program. In E3S Web of Conferences (Vol. 43, p. 01013). EDP Science. 